\title{
Isolation of bioactive compounds with tyrosinase inhibitory activity from the methanol extract of meniran herb (Phyllanthus niruri Linn.)
}

\author{
Syefira Salsabila ${ }^{\mathrm{ab}}$, Rika Hartati ${ }^{\mathrm{a}}$, Laode M.R. Al Muqarrabun ${ }^{\mathrm{b}}$, Nurinanda Prisky Qomaladewi ${ }^{\mathrm{b}}$, Ariranur \\ Haniffadli $^{\mathrm{a}}$, Andi Rifki Rosandy ${ }^{\mathrm{b}}$, Agus Chahyadi ${ }^{\mathrm{b}}$, Elfahmi ${ }^{\mathrm{ab}}$
}

aSchool of Pharmacy, Bandung Institute of Technology, Bandung 40132, West Java, Indonesia

bUniversity Center of Excellence for Nutraceuticals, Bioscience and Biotechnology Research Center, Bandung Institute of Technology, Bandung 40132, West Java, Indonesia

\begin{abstract}
Meniran (Phyllanthus niruri L.) is a wild plant in the Euphorbiaceae family which grows in tropical climates. The plant is known to possess antioxidant activity and is rich in phenolic compounds. Since plants with high phenolic content and high antioxidant activity are known to exhibit high tyrosinase inhibitory activity, the purpose of this study is to determine the inhibitory activity of the tyrosinase enzyme by the methanol extract of meniran $(P$. niruri L.) and to isolate secondary metabolites from the extract and fractions which exhibit inhibitory activity against tyrosinase. The in vitro tyrosinase inhibitory activity assay was conducted using the 96-well microplate method with kojic acid as the positive control, while the separation and purification of compounds were carried out using chromatography techniques. The methanol extract and $n$-hexane fraction showed tyrosinase inhibitory activity with $\mathrm{IC}_{50}$ of $11.05 \pm 0.16$ and $2.57 \pm 0.08 \mathrm{mg} / \mathrm{ml}$, respectively. Three bioactive compounds were succesfully isolated from the $n$-hexane fraction. Based on the UV and NMR spectra, compounds 1, 2, and 3 were identified as phyllanthin, phyltetralin, and hypophyllanthin, respectively. Furthermore, phyllanthin (1) was shown to demonstrate inhibitory activity against tyrosinase with IC 50 of $0.6322 \mathrm{mM}$. In conclusion, both meniran extract and phyllanthin (1) were found to exhibit inhibitory acitivity against the tyrosinase enzyme. In the future they can be candidates for the treatment against hyperpigmentation and also as an active ingredient in skincare formulations.
\end{abstract}

\section{Article history:}

Received 04 Feb 2022

Revised 24 Feb 2022

Accepted 26 Feb 2022

Available online 28 Feb 2022

Keywords:

Phyllanthus niruri

meniran herb

tyrosinase

phyllanthin

phyltetralin

hypophyllanthin

*Corresponding authors:

elfahmi@fa.itb.ac.id

\section{Introduction}

Human can experience skin damages caused by air pollution as well as long-term direct sunlight exposure (UV radiation) (Jesumani et al., 2020; Hashemi et al., 2019). The skin damages may include sunburn, early aging, inflammation, and both melanoma and non-melanoma skin cancer (Lukman et al., 2015; Ebrahimzadeh et al., 2014). Of the three types of UV radiation emitted by sun, i.e., UV-A (320-400 nm), UV-B (290-320 nm), dan UV-C (100-290 nm), only UV-A and UV-B can penetrate earth atmosphere, whereas UV-C is filtered out (Dutra et al., 2004). While UV-A may cause early aging symptoms on skin, UV-B can trigger sunburn, and stimulate the production of melanin as well as promote erythema (Dutra et al., 2004; Lukman et al., 2015).

Melanin is a pigment which plays an important role in protecting human skin from the damaging effects of UV radiation from the sun. The biosynthesis of melanin in plants and animals is regulated by a key enzyme called tyrosinase (Georgiev et al., 2013). Tyrosinase, which belongs to the polyphenol oxidase class, is an enzyme that catalyzes two reactions by responding to the hydroxylation of tyrosine into 3,4-hydroxyphenylalanine (L-DOPA) as well as the oxidation of L-DOPA into DOPA-quinone (Perera et al., 2018). Even though melanin serves a beneficial function for human, excess accumulation of the pigment (hyperpigmentation) in certain areas of human body may prove to bring about aesthetic problems. This issue has inspired researchers to discover new sources of tyrosinase inhibitors to prevent the hyperpigmentation of melanin with better safety and efficacy (Chang, 2009).

Natural products, especially medicinal plants, have been important sources for research to find new bioactive compounds (Ebrahimzadeh et al., 2014). Polyphenol group has been known as prominent sources of compounds with tyrosinase inhibitory activity (Masum et al., 2019), which include flavonoids, flavonoid glycosides, hydroquinone and its derivatives, chalcones, stilbene and its derivatives, coumarins, gallates (Lee et al., 2016; Kim and Uyama, 2005), lignins dan lignin glycosides (Wang et al., 2010), and lignans (Azhar-Ul-Haq et al., 2006; Zolghadri et al., 2019). In addition, long-chain lipids, steroids, and benzoate derivatives were also identified as potential tyrosinase inhibitors (Masum et al., 2019). One example medicinal plant known to contain polyphenol compounds is meniran herb.

Meniran (Phyllanthus niruri L.) is a plant belonging to the family Euphorbiaceae. It widely grows in humid and rocky regions (Nugrahani, 2013; Rivai et al., 2012; Pratiwi and Rivai, 2015). Meniran has been found to contain a wide range of compounds, including alkaloids, phenolics, flavonoids, saponins, catechuic tannins, gallic tannins, quinones, triterpenoids, coumarins, as well 
as essential oils (Tambunan et al., 2019; Chakravarthi et al., 2018). According to Nurcholis et al. (2012), the abundance of phenolic compounds in meniran is significantly high. Consequently, this makes the meniran extract potential as tyrosinase inhibitor and antioxidant, as high antioxidant activity often translates to high tyrosinase inhibitory activity (Mazlan et al., 2013).

This study aims to isolate and identify bioactive compounds from meniran herb ( $P$. niruri L.) with tyrosinase inhibitory activity. In this report, a study on the tyrosinase inhibitory activity of the methanol extract of meniran was carried out. Furthermore, a bioassay-guided isolation of bioactive compounds from the extract and organic fractions was conducted.

\section{Materials and methods}

\subsection{Materials}

Dried, powdered meniran herb (Phyllanthus niruri L.), nhexane, methanol $(\mathrm{MeOH})$, ethyl acetate (EtOAc), chloroform $\left(\mathrm{CHCl}_{3}\right)$, cerium sulphate $\left(\operatorname{Merck}^{\circledR}\right)$, acetonitrile $(\mathrm{AcN})\left(\operatorname{Merck}^{\circledR}\right)$, sulphuric acid, TLC plate silica gel $60 \mathrm{~F}_{254}$ (Merck $\left.{ }^{\circledR}\right)$, silica gel 60 (0.2-0.5 mm) for column chromatography (Merck $\left.{ }^{\circledR}\right)$, silica gel 60 $\mathrm{HF}_{254}$ for thin layer chromatography (Merck ${ }^{\circledR}$ ), silica gel $60 \mathrm{GF}_{254}$ (Merck ${ }^{\circledR}$ ), kojic acid (Sigma-Aldrich ${ }^{\circledR}$ ), tyrosinase enzyme from Agaricus bisporus (Catalog No. T3824, Sigma-Aldrich ${ }^{\circledR}$ ), L-DOPA (Sigma-Aldrich ${ }^{\circledR}$ ), Phyllanthin reference compound (MarkHerb ${ }^{\circledR}$, Bandung, Indonesia), potassium dihydrogen phosphate, dipotassium hydrogen phosphate trihydrate, sodium hydroxide, hydrochloric acid, toluene, ammonia, Dragendorff reagent, Mayer reagent, magnesium ( $\mathrm{Mg}$ ) powder, amyl alcohol, ferric chloride, gelatine, formaldehyde, sodium acetate, diethylether (DE), acetic anhydride.

\subsection{Phytochemical screening and physicochemical characterization}

Phytochemical screening was carried out on the dried powder and methanol extract to qualitatively identify the secondary metabolites, including alkaloids (Cordell, 1981), flavonoids
(Farnsworth, 1966), saponins (Depkes, 1995), tannins (gallic tannins dan catechuic tannins) (Procter et al., 1966; Farnsworth, 1966), quinones (Harborne, 1987), dan triterpenoids/steroids (Farnsworth, 1966). The characterization of the dried powder and extract included the dry loss, water content, total ash content, and acid-insoluble ash content, using standard methods from WHO (2011) and Kemenkes RI (2011).

\subsection{Tyrosinase inhibitory activity assay}

The in vitro tyrosinase inhibitory activity assay was conducted using dopachrome method with modification (Masuda et al., 2005), utilizing 96-well microplate reader. The samples tested for this bioactivity were the $\mathrm{MeOH}$ extract, three fractions ( $n$-hexane, EtOAc, and water), the subfractions from VLC (subfractions B-H), and compound 1 , with kojic acid as the positive control $\left(\mathrm{IC}_{50}=2.71\right.$ $\pm 0.06 \mu \mathrm{g} / \mathrm{mL}$ ). The microplate was divided into four test sections, i.e., section A (control) with $120 \mu \mathrm{L}$ of $0.1 \mathrm{M}$ phosphate buffer (pH $=6.8$ ) and $40 \mu \mathrm{L}$ of tyrosinase enzyme $(400 \mathrm{U} / \mathrm{mL})$; section $\mathrm{B}$ (blank control) with $160 \mu \mathrm{L}$ of phosphate buffer; section C (sample) with $80 \mu \mathrm{L}$ of phosphate buffer, $40 \mu \mathrm{L}$ of sample solution, and $40 \mu \mathrm{L}$ of tyrosinase enzyme; and section D (blank sample) with $120 \mu \mathrm{L}$ of phosphate buffer and $40 \mu \mathrm{L}$ of sample solution. Each section was incubated at $23^{\circ} \mathrm{C}$ for $10 \mathrm{~min}$. Afterwards, $40 \mu \mathrm{L}$ of $2.5 \mathrm{mM}$ L-DOPA was added into each well, followed by further incubation at $23^{\circ} \mathrm{C}$ for $10 \mathrm{~min}$. Upon completion, the UV absorbance of each well was measured and recorded at $\lambda 475 \mathrm{~nm}$. The inhibition percentage was calculated using the following equation:

$\%$ tyrosinase inhibition $=\left[\frac{(\mathrm{A}-\mathrm{B})-(\mathrm{C}-\mathrm{D})}{(\mathrm{A}-\mathrm{B})}\right] \times 100 \%$

where A, B, C, and D are the absorbances of control, blank control, samples, and blank sample, respectively. The $\mathrm{IC}_{50}$ value was determined by non-linear regression analysis.

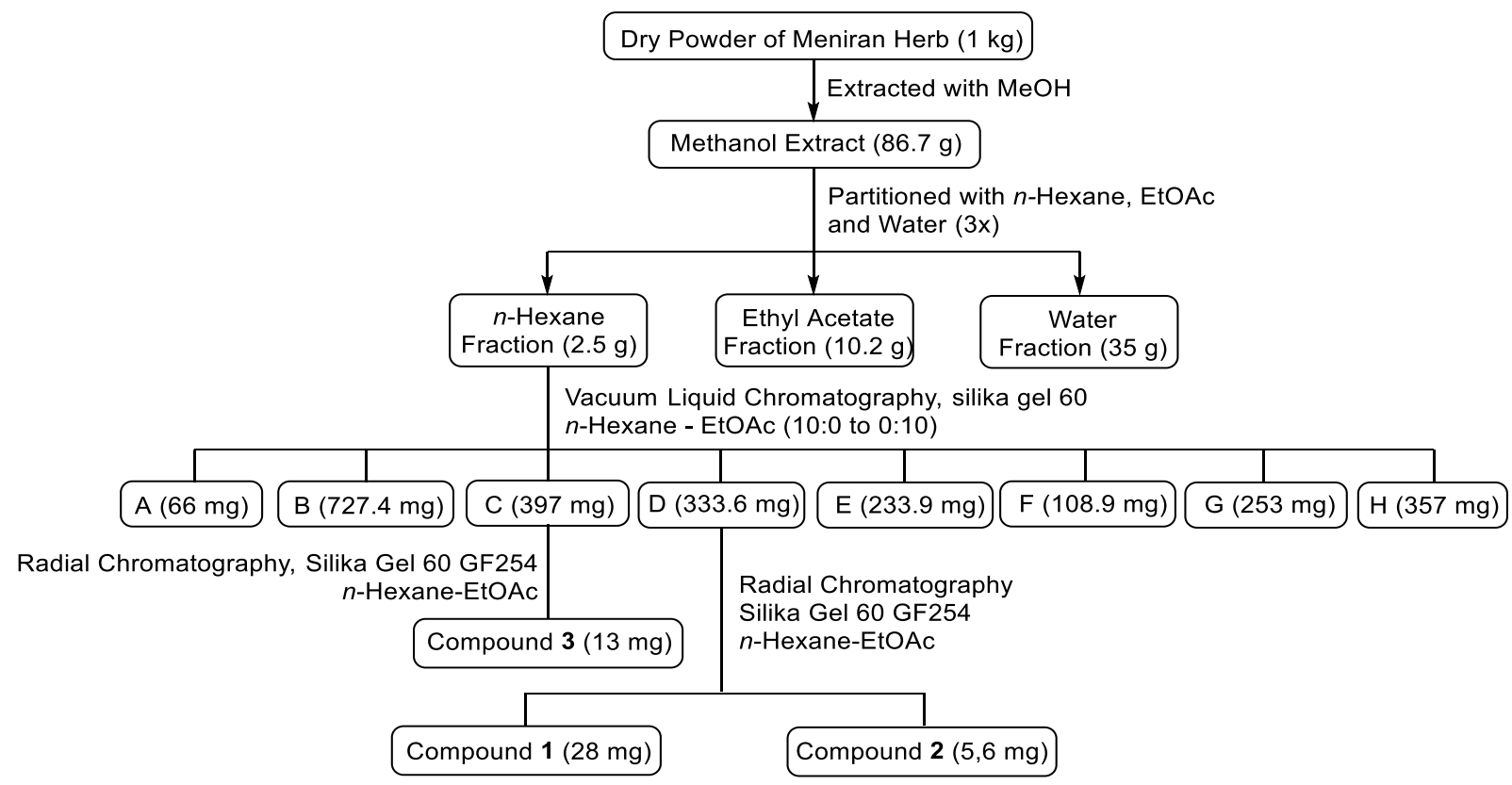

Fig. 1. Separation and purification diagram

\subsection{Bioassay-guided isolation of secondary metabolites from meniran ( $P$. niruri L.)}

The dried, powdered meniran (1 kg) was extracted with maceration method using $5 \mathrm{~L}$ of $\mathrm{MeOH}$ for $3 \times 24 \mathrm{~h}$ at room temperature to give brown crude extract with $9.8 \%$ yield. The extract was subjected to liquid-liquid fractionation using $n$-hexane, EtOAc, and water. All the three fractions were subjected to tyrosinase inhibitory activity assay. The $n$-hexane fraction $(2.5 \mathrm{~g})$ which exhibited the highest activity, was further fractionated using Vacuum Liquid Chromatography (VLC) and eluted with increasing polarity of $n$-hexane-EtOAc (10:0 to $0: 10$ ) to give eight subfractions 
(A-H). Among the eight subfractions, the subfractions C (397 mg) and $\mathrm{D}(333.6 \mathrm{mg})$ were found to possess the highest tyrosinase inhibitory activity. Subfraction D was further separated using Radial Chromatography (RC), resulting in 17 subfractions (D1-D17). Subsequent separation on RC was carried out on subfraction D5 to yield compound $1(28 \mathrm{mg})$ and $2(5.6 \mathrm{mg})$. Subfraction C from VLC was subjected to RC using $n$-hexane:EtOAc (9:1) to give 17 subfractions (C1-C17). Subfraction C6 was further purified using RC to yield compound $3(13 \mathrm{mg})$. All stages of separation and purification were monitored using Thin Layer Chromatography (TLC) with $n$-hexane-EtOAc as the solvent system.

The purity of the isolated compounds was confirmed with High Performance Liquid Chromatography (HPLC) LC-20AD Shimadzu ${ }^{\circledR}$ (Japan) using LiChrospher® $100 \mathrm{RP}-185 \mu \mathrm{m}$ column $(250 \mathrm{~mm}$ length, $4 \mathrm{~mm}$ diameter, $20 \mathrm{~mm}$ pre-column). A reverse phase HPLC assay was carried out using an isocratic elution with a flow rate of $1 \mathrm{~mL} / \mathrm{min}$, a column temperature of $30^{\circ} \mathrm{C}$, a mobile phase of Acetonitrile-Water (60:40, v/v) with $0.01 \%$ ortho-phosphoric acid and a detection wavelength of $280 \mathrm{~nm}$. UV Spectra were recorded on Beckman Coulter DU ${ }^{\circledR 720} \mathrm{UV} /$ Vis spectrophotometer. The ${ }^{1} \mathrm{H}$ and ${ }^{13} \mathrm{C}-\mathrm{NMR}$ spectra were recorded on Bruker ${ }^{\circledR}$ spectrometer operating at $400 \mathrm{MHz}$.

Phyllanthin (1). White amorphous powder. UV-Vis $\lambda_{\max }$ : 230, $280 \mathrm{~nm} .{ }^{1} \mathrm{H}$ NMR $\left(\mathrm{CDCl}_{3}, 400 \mathrm{MHz}\right): \delta_{\mathrm{H}} 6.78(2 \mathrm{H}, d, J=8, \mathrm{H}-5 / 5$ '), $6.67(2 \mathrm{H}, d d, J=2.08,7.96, \mathrm{H}-6 / 6$ ') $6.64(2 \mathrm{H}, d, J=1.92, \mathrm{H}-$ 2/2'), 3.88 (6H, s), $3.83(6 \mathrm{H}, s), 3.34$ (4H, m, H-9/9'), $3.32(6 \mathrm{H}, s$, 9'- $\left.\mathrm{OCH}_{3}\right), 2.68$ (4H, m, H-7/7'), 2.06 (2H, m, H-8/8').

Phyltetralin (2). White amorphous powder. UV-Vis $\lambda_{\max }: 230$ (sh), $281 \mathrm{~nm} .{ }^{1} \mathrm{H} \mathrm{NMR}\left(\mathrm{CDCl}_{3}, 400 \mathrm{MHz}\right): \delta_{\mathrm{H}} 6.83(1 \mathrm{H}, d, J=8.2$, H-5'), 6.73 (1H, $d d, J=8.2,1.96, \mathrm{H}-6 / 6$ ') 6.65 (1H, $d, J=1.92$, $\mathrm{H}-2 / 2$ ') 6.63 (1H, $s, \mathrm{H}-5), 6.25$ (1H, $s, \mathrm{H}-2), 4.01(1 \mathrm{H}, d, J=10.32$, H-7'), $3.91(3 \mathrm{H}, s), 3.87(3 \mathrm{H}, s), 3.83(3 \mathrm{H}, s), 3.61(3 \mathrm{H}, s), 3.48$ $(2 \mathrm{H}, m), 3.39(1 \mathrm{H}, m), 3.38(3 \mathrm{H}, s), 3.29(3 \mathrm{H}, s), 3.11(1 \mathrm{H}, d d, J$ =9.52, 3.32), $2.86(2 \mathrm{H}, d, J=7.24), 2.20(1 \mathrm{H}, m), 1.84(1 \mathrm{H}, m)$. Hypophyllanthin (3). White crystalline. UV-Vis $\lambda_{\max }$ : 230 (sh), 278 nm. ${ }^{1} \mathrm{H}$ NMR $\left(\mathrm{CDCl}_{3}, 400 \mathrm{MHz}\right): \delta_{\mathrm{H}} 6.34(1 \mathrm{H}, s, \mathrm{H}-2), 2.81(1 \mathrm{H}, d d$, $J=4.55,15.63, \mathrm{H}-7), 2.75$ (1H, $m, \mathrm{H}-7), 2.00(1 \mathrm{H}, m, \mathrm{H}-8), 3.44$ $(1 \mathrm{H}, d d, J=3.99,9.31, \mathrm{H}-9), 3.37(1 \mathrm{H}, m, \mathrm{H}-9), 6.75(1 \mathrm{H}, d, J=$ 8.18, H-2'), 6.65 (1H, dd, $J=2.04,8.04, \mathrm{H}-5$ '), 6.68 (1H, $d, J=$ 2.01, H-6'), 4.10 (1H, $d, J=7.94, \mathrm{H}-7$ '), 1.91 ( $1 \mathrm{H}, t d, J=3.90$, 8.59, 9.42, H-8'), 3.39 (1H, $m, \mathrm{H}-9$ '), 3.25 (1H, $d d, J=3.45$, 9.52, H-9'), $3.82\left(3 \mathrm{H}, s, 3-\mathrm{OCH}_{3}\right), 3.34\left(3 \mathrm{H}, s, 9-\mathrm{OCH}_{3}\right), 3.86(3 \mathrm{H}, s, 3$ ' $\left.\mathrm{OCH}_{3}\right), 3.88\left(3 \mathrm{H}, s, 4^{\prime}-\mathrm{OCH}_{3}\right), 3.32\left(3 \mathrm{H}, s, 9^{\prime}-\mathrm{OCH}_{3}\right), 5.66(1 \mathrm{H}, d, J$ $\left.=1.2,-\mathrm{O}-\mathrm{CH}_{2}-\mathrm{O}\right), 5.74\left(1 \mathrm{H}, d, J=1.2,-\mathrm{O}-\mathrm{CH}_{2}-\mathrm{O}\right) .{ }^{13} \mathrm{C} \mathrm{NMR}\left(\mathrm{CDCl}_{3}\right.$, $100 \mathrm{MHz}$ ): $\delta_{\mathrm{C}} 131.8$ (C-1), 106.5 (C-2), 142.1 (C-3), 133.3 (C-4), 147.0 (C-5), 115.1 (C-6), 33.3 (C-7), 36.6 (C-8), 75.4 (C-9), 138.0 (C-1'), 110.6 (C-2'), 148.5 (C-3'), $\delta 147.1$ (C-4'), 120.4 (C-5'), 111.8 (C-6'), 41.9 (C-7'), 45.4 (C-8'), 71.8 (C-9'), 55.9 (3- $\left.-\mathrm{OCH}_{3}\right)$, $58.9\left(9-\mathrm{OCH}_{3}\right), 55.8\left(3^{\prime}-\mathrm{OCH}_{3}\right), 56.4\left(4^{\prime}-\mathrm{OCH}_{3}\right), 58.9\left(9^{\prime}-\mathrm{OCH}_{3}\right)$, 101.1 (-O- $\left.\mathrm{CH}_{2}-\mathrm{O}-\right)$.

\section{Results and discussion}

\subsection{Phytochemical screening and physicochemical characterization}

The phytochemical screening was done to identify the types of chemical constituents in the dried powder and $\mathrm{MeOH}$ extract of the meniran herb. The qualitative screening showed that both the dried powder and the extract contain flavonoids, phenolics, saponins, gallic tannins, catechuic tannins, quinones, and triterpenoids/steroids, which have also previously been reported by Obianime and Uche (2010) and Okwute Simon et al. (2014).

Secondary metabolites compounds with polyphenol groups have many biological activities (Lee et al., 2016). Polyphenols are widely distributed in nature and are the largest group of secondary metabolites as tyrosinase inhibitors (Masum et al., 2019). This group includes flavonoids, flavonoids glycosides, hydroquinones and their derivatives, chalcones, stilbenes and their derivatives, coumarins (Lee et al., 2016), lignins and lignin glycosides (Wang et al., 2010), and lignans (Azhar-Ul-Haq et al., 2006; Zolghadri et al., 2019; Singh and Ahmad, 2020).

Physicochemical characterization on the dried powder and extract of meniran herb was carried out to ensure uniformity of quality of sample in order to meet the requirements of the standars dried powdered and extracts that have been set. The characterization for both samples was performed in triplicate, and the results are displayed in Table 1.

Table 1. Physicochemical characterization of the dried powder and extract of meniran herb

\begin{tabular}{|c|c|c|}
\hline \multirow{2}{*}{ Parameter } & \multicolumn{2}{|c|}{ Sample } \\
\hline & Dried powder (\%) & Extract (\%) \\
\hline Dry loss & $14.26 \pm 0.29$ & - \\
\hline Water content & $6.61 \pm 2.87$ & $14.26 \pm 0.29$ \\
\hline Total ash content & $14.86 \pm 1.04$ & $5.48 \pm 0.05$ \\
\hline Acid-insoluble ash content & $6.13 \pm 0.61$ & $0.12 \pm 0.02$ \\
\hline
\end{tabular}

Results showed that the maceration process using $\mathrm{MeOH}$ seemed to have significantly removed the ash contents from extract. On the other hand, the use of $\mathrm{MeOH}$ as the extraction solvent might have contributed in the escalated water content in the extract compared to the the dried powder. This could be due to the $\mathrm{MeOH}$ used was technical grade which might contain a certain abundance of water.

\subsection{Bioassay-guided isolation of bioactive compounds from meniran $(P$. niruri L.)}

One of approaches that have been used in isolating bioactive compounds from plants is the bioactivity-guided fractionation. With this method, the fractions with potential bioactivity are further pursued for the isolation and purification of their bioactive chemical constituents. In addition, using comparison between the bioactivity of the fractions and that of the single compounds may give a deeper insight on the possible occurence of either synergestic or antagonistic relationship between the compounds contained in the fractions. In this study, a bioassay-guided isolation of bioactive compounds with tyrosinase inhibitory activity was carried out. This work aimed to specifically target only compounds from the fractions which exhibited the highest activity in inhibiting tyrosinase enzyme.

The $\mathrm{MeOH}$ extract of meniran herb underwent liquid-liquid fractionation which resulted in three major fractions, i.e., the $n$ hexane, EtOAc, and water fractions. By using kojic acid as the positive control for the tyrosinase inhibitory activity assay (Macrini et al., 2009), it was revealed that the $n$-hexane fraction exhibited the highest \% inhibition ( $\mathrm{IC}_{50}=2.57 \pm 0.08 \mathrm{mg} / \mathrm{ml}$ ) among the three major fractions (Fig. 2). Moreover, the inhibition of the tyrosinase enzyme from $n$-Hexane fraction in Fig. 2 shows dosedependently increased. The $\mathrm{IC}_{50}$ of the $n$-hexane fraction was lower than that of the $\mathrm{MeOH}$ crude extract $\left(\mathrm{IC}_{50}=11.05 \pm 0.16 \mathrm{mg} / \mathrm{ml}\right.$ ), indicating that a better inhibitory activity could be achieved by simplifying the chemical composition of the extract into fractions. In addition, it was understood that the increase in the concentration of the $n$-hexane fraction resulted in a significant improvement in the inhibitory activity, especially from $2 \mathrm{mg} / \mathrm{mL}$ to $4 \mathrm{mg} / \mathrm{mL}$. Similar trend was also observed in the other two fractions, albeit not as considerable as that of the $n$-hexane fraction.

Several subfractions, obtained from the $n$-hexane fraction using VLC, were subsequently investigated for their tyrosinase inhibitory 
activity. The assay was conducted in two different concentrations, i.e., at 1 and $2 \mathrm{mg} / \mathrm{mL}$. The bioactivity assay results are displayed in Fig. 2. Subfraction $\mathrm{C}$ was selected for further purification stages due to showing the highest \% inhibition, indicating that the subfraction possibly contained compounds with considerable tyrosinase inhibitory activity. After subsequent purification using RC, compound $\mathbf{3}$ was obained as white crystalline from the subfraction. Meanwhile, owing to exhibiting a significant increase in the \% inhibition with the increase in concentration, subfraction D was also subjected to RC for further purification to yield compound 1 and 2.

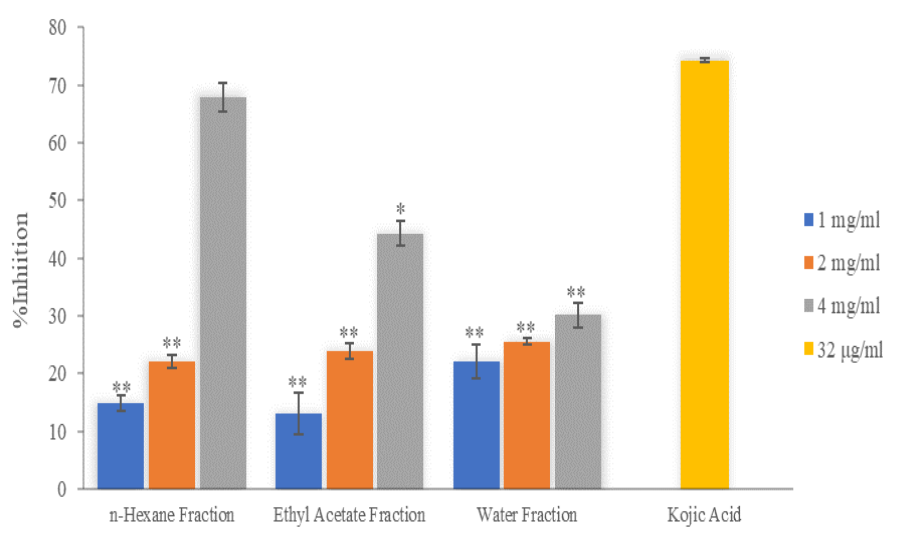

Fig. 2. Tyrosinase inhibitory activity of the three major fractions of meniran herb. $* \mathrm{p}<0.05$ and $* * \mathrm{p}<0.01$ compared to positive control (kojic acid). All data are expressed as mean \pm SD of 3 replicates.

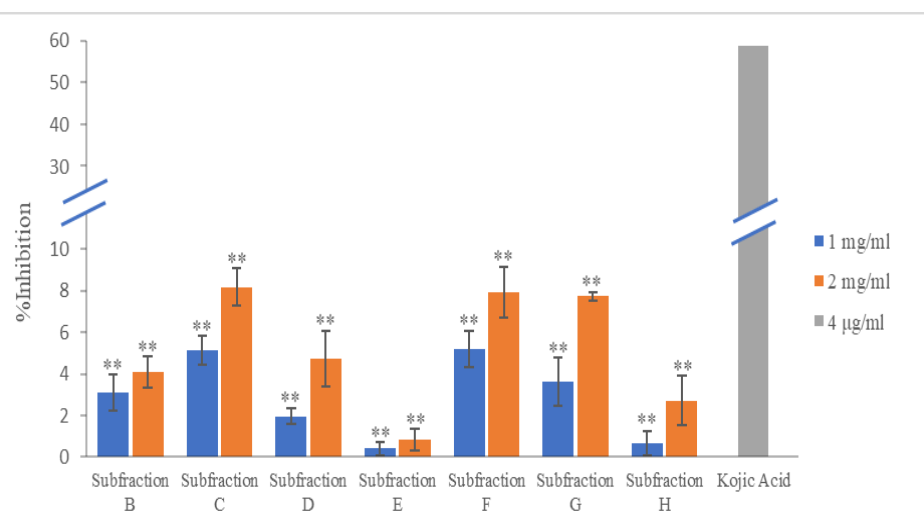

Fig. 3. Tyrosinase inhibitory activity of the subfractions from the $n$-hexane fraction. $* \mathrm{p}<0.05$ and $* * \mathrm{p}<0.01$ compared to positive control (kojic acid). All data are expressed as mean \pm SD of 3 replicates.

\subsection{Characterization of the isolated compounds}

The purity of the active compound was analyzed using HPLC. It was found that the purity of compounds 1,2 , and 3 was $98.6 \%$, $93.6 \%$, and $97.1 \%$, respectively (Fig. 4). The structures of the isolated compounds were elucidated using several spectroscopic methods including UV-Vis and NMR $1 \mathrm{D}\left({ }^{1} \mathrm{H}\right.$ and $\left.{ }^{13} \mathrm{C}\right)$, and by comparing with reported data. The three compounds were identified as phyllanthin (1), phyltetralin (2), and hypophyllanthin (3).

Compound 1 (phyllanthin), $\mathrm{C}_{24} \mathrm{H}_{34} \mathrm{O}_{6}$, was obtained as white amorphous powder. The UV spectrum showed maximum absorbance at $\lambda_{\max }$ of 230 and $280 \mathrm{~nm}$, which indicated the presence of conjugated double bonds in the structure. This spectral data matches the UV absorbance data from literatures (Azam and Ajitha, 2017; Khabiya et al., 2014). The ${ }^{1} \mathrm{H}$ NMR spectrum revealed three signals of aromatic protons with chemical shift of over $6 \mathrm{ppm}$, integrating for 2 protons each. These protons appear as two doublets a doublet of doublet. Proton at $\delta_{\mathrm{H}} 6.67$ (H-6/6', $d d, J=2$ and $8 \mathrm{~Hz})$ are in ortho and meta positions to $\delta_{\mathrm{H}} 6.78(\mathrm{H}-5 / 5, d, J$ $=8 \mathrm{~Hz})$ and $6.64(\mathrm{H}-2 / 2, d, J=1.92 \mathrm{~Hz})$, respectively. The integration of two protons for each signal suggests that the compound features two mirroring aromatic rings with identical chemical environment. Additionally, the presence of three singlet signals at 3.88, 3.83, and $3.32 \mathrm{ppm}$ constituting 6 protons each revealed that there are six methoxy groups in the structure, four of which (3.88 and $3.83 \mathrm{ppm}$ ) being directly attached to aromatic rings, while the other two are bound to the aliphatic moiety of the compound. Furthermore, a deshielded aliphatic multiplet signal (3.34 ppm) integrating for four protons represents two symmetrical methylene groups which are bound to oxygen atoms, i.e., the aliphatic methoxy groups. With the presence of the other two identical methylene groups at $2.68 \mathrm{ppm}$, as well as two mirroring methine groups at $2.06 \mathrm{ppm}$, it is strongly believed that compound 1 can be identified as phyllanthin, $\mathrm{C}_{24} \mathrm{H}_{32} \mathrm{O}_{6}$ (Fig. 3), which is a compound belonging in lignan group.

The ${ }^{1} \mathrm{H}$ NMR data was also compared with that was reported in the literature (Paul et al., 2019) to confirm the identity of the compound. Phyllanthin (1) has been previously isolated from $P$. niruri L. (Row et al., 1964; Anjaneyulu et al., 1973; Maciel et al., 2007) as well as from Phyllanthus amarus (Tripathi et al., 2006). Compound 1 was subsequently subjected to tyrosinase inhibitory activity assay, and the result showed that the compound exhibited inhibitory activity with IC50 value of $264.57 \pm 3.74 \mu \mathrm{g} / \mathrm{mL}(0.6322$ $\mathrm{mM}$ ), significantly higher than that of kojic acid $\left(\mathrm{IC}_{50}=0.0191\right.$ $\mathrm{mM}$ ). This indicates that phyllanthin is approximately weaker in inhibiting tyrosinase enzyme compared to kojic acid.

Compound 2 (phyltetralin), $\mathrm{C}_{24} \mathrm{H}_{32} \mathrm{O}_{6}$, was isolated as white amorphous powder. The UV-Vis spectral data showed similar characteristic to that of compound 1 , with maximum absorbances at 230 and $281 \mathrm{~nm}$. Overall, the structure of 2 is nearly identical to that of 1 (Fig. 3). The only difference is that one of the aromatic carbons (C-6) forms a covalent bond with benzylic carbon (C-7'). This results in the chemical environment of the whole structure changing, cancelling the symmetry of what was there in $\mathbf{1}$. Thus, compound 2 features more proton signals on NMR. According to the ${ }^{1} \mathrm{H}$ NMR spectrum, the methoxy groups appeared as six singlet signals integrating for three protons each at $\delta_{\mathrm{H}}$ ranging from 3.29 $3.91 \mathrm{ppm}$. One of the two aromatic rings only comprises two proton at $6.25 \mathrm{ppm}(\mathrm{H}-2, s)$ and $6.63 \mathrm{ppm}(\mathrm{H}-5, s)$, while the other ring shows similar characteristic as the aromatic rings of 1 , featuring three types of proton signal (H-2', H-5', and H-6'). Furthermore, the signal of benzylic methylene protons $\mathrm{H}^{-} \mathbf{7}^{\prime}(2.68 \mathrm{ppm})$ in $\mathbf{1}$ is replaced by a more deshielded methine proton $\mathrm{H}-7^{\prime}$ ' in 2 (4.01 ppm). The ${ }^{1} \mathrm{H}$ NMR spectrum along with data comparison with literature (Anjaneyulu et al., 1973) confirmed that compound $\mathbf{2}$ is phyltetralin.

Compound 3 (hypophyllanthin) was obtained as white crystalline with chemical formula $\mathrm{C}_{24} \mathrm{H}_{30} \mathrm{O}_{7}$. The UV-Vis spectral data showed similar characteristic to that of compound 1 , with maximum absorbances at 230 and $278 \mathrm{~nm}$. Analysis with ${ }^{13} \mathrm{C}$ NMR revealed that this compound consists of 24 carbons. There are 12 aromatic carbon signals (C-1/C-1' - C-6/-C6') with chemical shifts ranging from 106.5 - $148.5 \mathrm{ppm}$, comprising of eight quarternary carbons and four methines. Another highly-deshielded carbon signal at $\delta_{\mathrm{C}} 101.1 \mathrm{ppm}$ represents a methylene dioxy carbon (-O$\left.\mathrm{CH}_{2}-\mathrm{O}-\right)$ attached to one aromatic ring at C-4 and C-5. 
$\mathrm{mv}$

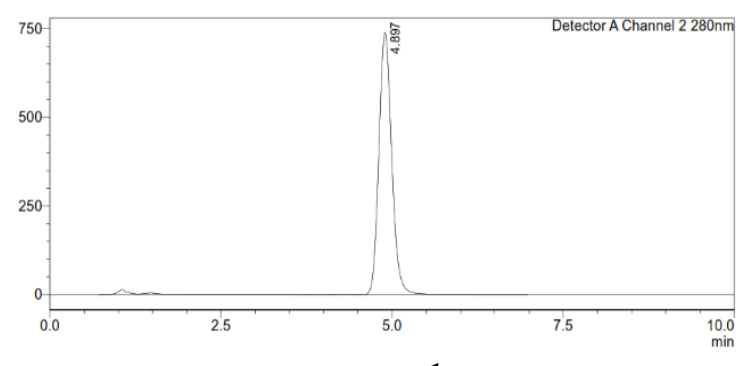

1
$\mathrm{mV}$

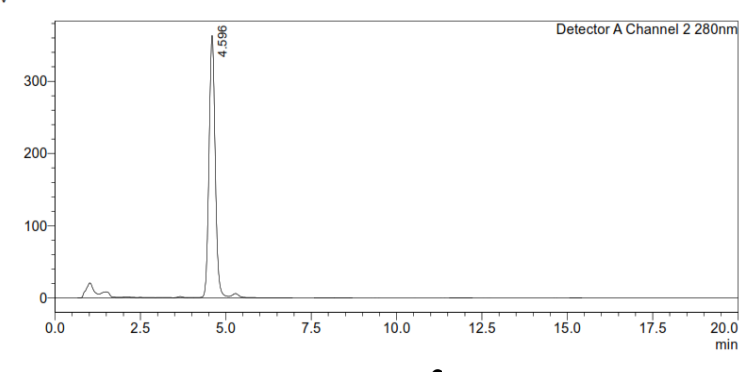

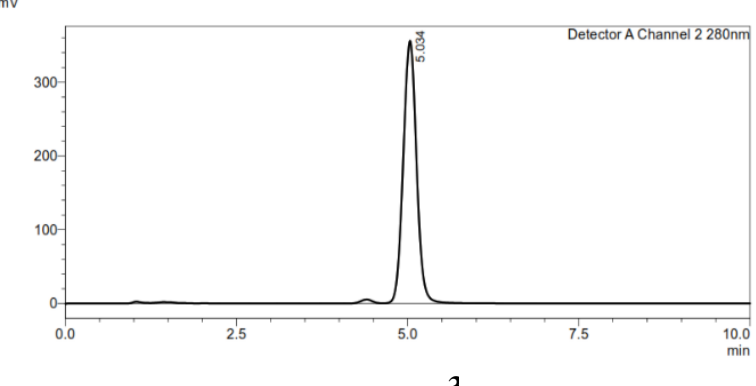

2

Fig. 4. Chromatograms of compounds 1, 2, and 3<smiles>COCC(Cc1ccc(OC)c(OC)c1)C(COC)Cc1ccc(OC)c(OC)c1</smiles>

1<smiles>COCC1Cc2cc(OC)c(OC)cc2[C](c2ccc(OC)c(OC)c2)C1COC</smiles>

2<smiles>COCC1Cc2cc(OC)c3c(c2[C](c2ccc(OC)c(OC)c2)[C@H]1COC)OCO3</smiles>

3

Fig. 5. Structures of compounds 1-3

As a result of the structure assymmetry, carbons C-8 (36.6 ppm) and C-8' (45.4 ppm) appear as different signals. The same also applies to C-9 (75.4 ppm) and C-9' (71.8 ppm), as well as other carbons in the aromatic rings. Due to covalent bond formed between C-6 and C-7', what were a methine and methylene in compound 1 have turned into a quarternary carbon and a methine for C--6 and C-7', respectively.

The ${ }^{1} \mathrm{H}$ NMR spectrum of compound 3 complemented the data from the ${ }^{13} \mathrm{C}$ NMR. The methoxy groups appeared as five singlet signals integrating for three protons each at $\delta_{\mathrm{H}}$ ranging from $3.32-$ $3.88 \mathrm{ppm}$. The chemically-nonequivalent methylene dioxy protons are observed as two separated doublet signals at $5.66(1 \mathrm{H}, d, J=$ $1.2 \mathrm{~Hz})$ and $5.74(1 \mathrm{H}, d, J=1.2 \mathrm{~Hz})$. One of the two aromatic rings only comprises one proton at $6.34 \mathrm{ppm}(\mathrm{H}-2, s)$, while the other ring shows similar characteristic as the aromatic rings of phyllanthin (1) and phyltetralin (2), featuring three types of proton signal (H-2', H-5', and H-6'). By comparing the NMR spectral data with literature (Khabiya et al., 2014; Noor et al., 2019), compound $\mathbf{3}$ is identified as hypophyllanthin, which is known as one of the major chemical constituents found in meniran (Anjaneyulu et al., 1973). Hypophyllanthin has also been reported in previous studies from P. niruri L. (Noor et al., 2019; Somanabandhu et al., 1993; Maciel et al., 2007).

\section{Conclusion}

The bioassay-guided isolation of meniran herb ( $P$. niruri L.) resulted in the isolation of three lignan compounds, namely phyllanthin (1), phyltetralin (2), and hypophyllanthin (3). Compound 1, along with the $\mathrm{MeOH}$ extract and fractions from liquid-liquid fractionation of meniran herb were investigated for their in vitro tyrosinase inhibitory activity. The results showed that the $n$-hexane fraction exhibited the highest activity among the extract and the other fractions, while compound 1 demonstrated a weaker activity compared to kojic acid standard. Ultimately, this study is the first to report tyrosinase inhibitory activity of meniran extract and phyllanthin.

\section{Acknowledgement}

This work was partially funded by the Ministry of Finance, Republic of Indonesia, under scheme "Riset Inovasi Produktif (RISPRO) Invitasi LPDP" with grant number of PRJ-24/LPDP/2019.

\section{Conflict of interest}

The authors declare there is no conflict of interest in this study. 


\section{References}

Anjaneyulu ASR, Rao KJ, Row LR, Subrahmanyam C. 1973. Isolation and structural elucidation of three new lignans from the leaves of Phyllanthus niruri Linn. Tetrahedron 29: 1291-8. doi: 10.1016/S00404020(01)83146-X

Azam M, Ajitha M. 2017. Phyllanthin: a potential lead molecule for the future needs. Int $J$ Pharmacog Phytochem Res. 9(08): 1-9. doi:0.25258/phyto.v9i08.9615

Azhar-Ul-Haq, Malik A, Khan MTH, Anwar-Ul-Haq, KhanSB, Ahmad A, Choudhary MI. 2006. Tyrosinase inhibitory lignans from the methanol extract of the roots of Vitex negundo Linn. and their structure-activity relationship. Phytomedicine 13(4): 255-60. doi: 10.1016/j.phymed.2004.09.001

Chakravarthi PV, Murugesan S, Arivuchelvan A, Sukumar K. 2018. In vitro xanthine oxidase inhibitory activity of Piper betle and Phyllanthus niruri. J Pharmacog Phytochem 7(5): 959-61.

Chang TS. 2009. An updated review of tyrosinase inhibitors. Int $J$ Mol SCi 10(6): 2440-75. doi: 10.3390/ijms10062440

Cordell GA. 1981. Introduction to alkaloids: a biogenetic approach. Chicago: University of Illinois.

Depkes RI. 1995. Materia medika indonesia jilid VI. Jakarta: Departemen Kesehatan Republik Indonesia.

Dutra EA, Da Costa E Oliveira DAG, Kedor-Hackmann ERM, Miritello Santoro MIR. 2004. Determination of sun protection factor (SPF) of sunscreens by ultraviolet spectrophotometry. Braz J Pharm Sci 40(3): 381-5. doi: 10.1590/S1516-93322004000300014

Ebrahimzadeh MA, Enayatifard R, Khalili M, Ghaffarloo M, Saeedi M, Charati JY. 2014. Correlation between sun protection factor and antioxidant activity, phenol and flavonoid contents of some medicinal plants. Iran $J$ Pharm Res 13(3): 1041-1048. doi: 10.22037/ijpr.2014.1554

Farnsworth NR. 1966. Biological and phytochemical screening of plants. $J$ Pharma Sci 55(3): 225-76. doi: 10.1126/science.151.3712.874

Georgiev L, Chochkova M, Totseva I, Seizova K, Marinova E, Ivanova G, Ninova M, Najdenski H, Milkova T. 2013. Anti-tyrosinase, antioxidant and antimicrobial activities of hydroxycinnamoylamides. Med Chem Res 22(9): 4173-82. doi: 10.1007/s00044-012-0419-x

Harborne JB. 1987. Phytochemistry methods: modern guide for plant analysis (in Indonesian). Bandung: ITB Press.

Hashemi Z, Ebrahimzadeh MA, Khalili M. 2019. Sun protection factor, total phenol, flavonoid contents and antioxidant activity of medicinal plants from Iran. Trop J Pharm Res 18(7): 1443-8. doi: 10.4314/tjpr.v18i7.11

Jesumani V, Du H, Pei P, Aslam M, Huang N. 2020. Comparative study on skin protection activity of polyphenol-rich extract and polysacchariderich extract from Sargassum vachellianum. Plos One 15(1): 1-17. doi 10.1371/journal.pone.0227308

Kemenkes RI. 2011. Indonesian herbal pharmacopoia - Supplement II (in Indonesian). Jakarta: Direktorat Jenderal Bina Kefarmasian dan Alat Kesehatan - Kemenkes RI.

Khabiya R, Upadhyay D, Srivastava A, Anandjiwala S. 2014. Simultaneous quantification of three bioactive lignans, viz., phyllanthin, hypophyllanthin, and niranthin from Phyllanthus amarus using highperformance thin-layer chromatography. J Planar Chromat-Modern TLC 27(4): 281-6. doi: 10.1556/JPC.27.2014.4.8

Kim YJ, Uyama H. 2005. Tyrosinase inhibitors from natural and synthetic sources: structure, inhibition mechanism and perspective for the future. Cell Mol Life Sci 62(15): 1707-23. doi: 10.1007/s00018-005-5054-y

Lee SY, Baek N, Nam TG. 2016. Natural, semisynthetic and synthetic tyrosinase inhibitors. $J$ Enzym Inhib Med Ch 31(1): 1-13 doi: 10.3109/14756366.2015.1004058

Lukman M, Ulfa M, Syahruni R, Fatmawati A. 2015. Antityrosinase effect of botanicals: a review of medicinal plants cosmetic. $J$ Chem Pharmaceut Res 7(5): 716-22.

Maciel MA, Cunha AF, Dantas TNC, Kaiser CR. 2007. NMR Characterization of bioactive lignans from Phyllanthus amarus Schum \& Thorn. Annals of Magnetic Resonance 6(3): 76-82.

Macrini DJ, Suffredini IB, Varella AD, Younes RN, Ohara MT. 2009. Extracts from Amazonian plants have inhibitory activity against tyrosinase: An in vitro evaluation. Braz $J$ Pharm Sci 45(4): 715-21. doi: 10.1590/S1984-82502009000400015

Masuda T, Yamashita D, Takeda Y, Yonemori S. 2005. Screening for tyrosinase inhibitors among extracts of seashore plants and identification of potent inhibitors from garcinia subelliptica. Biosci
Biotechnol Biochem 69(1): 197-201. doi: 10.1271/bbb.69.197

Masum MN, Yamauchi K, Mitsunaga T. 2019. Tyrosinase inhibitors from natural and synthetic sources as skin-lightening agents. Rev in Agr Sci 7: 41-58. doi: 10.7831/ras.7.41

Mazlan NA, Mediani A, Abas F, Ahmad S, Shaari K, Khamis S, Lajis NH. 2013. Antioxidant, antityrosinase, anticholinesterase, and nitric oxide inhibition activities of three Malaysian Macaranga species. Sci World J 2013(312741): 1-8. doi: 10.1155/2013/312741

Noor NAM, Nafiah MA, Johari SATT, Hasnan MHH, Tan SP, Liew SY, Supratman U. 2019. Anticancer effect of hypophyllanthin, niranthin and lintetralin from Phyllanthus amarus on hela cells and nih/3t3 cells. IJRTE 8(2): 106-10. doi: 10.35940/IJRTE

Nugrahani SS. 2013. Comparative analysis of the effectiveness of extracts of the roots, stems, and leaves of meniran herbs in reducing blood glucose levels in mice (in Indonesian). Unnes $J$ Public Health 2(1): 1-9. doi: 10.15294/ujph.v2i1.3040

Nurcholis W, Priosoeryanto BP, Purwakusumah ED, Katayama T, Suzuki, T. 2012. Antioxidant, cytotoxic activities and total phenolic content of four indonesian medicinal plants. Jurnal Kimia VALENSI 2(4): 501-10. doi: $10.15408 / \mathrm{jkv} . v 2 \mathrm{i} 4.267$

Obianime A, Uche F. 2010. The phytochemical screening and the effects of methanolic extract of Phyllanthus amarus leaf on the biochemical parameters of Male guinea pigs. J Appl Sci Environ Manag 12(4). doi: 10.4314/jasem.v12i4.55222

Okwute Simon K, Okolo Simon C, Okoh-Esene R, Olajide Olutayo O. 2014. Biological and chemical evaluation of the extracts of the leaf of Phyllanthus amarus Schum. Int J ChemTech Res 7(5): 2347-54.

Paul S, Patra D, Kundu R. 2019. Lignan enriched fraction (LRF) of Phyllanthus amarus promotes apoptotic cell death in human cervical cancer cells in vitro. Sci Rep 9(1): 1-14. doi: 10.1038/s41598-01951480-7

Perera H, Pradeep A, Devinda K, Ratnayake R, Gunawardhana D, Jayasinghe J. 2018. Antityrosinase activities of thespesia populnea bark and phyllanthus emblica fruit. J Advan Med Pharm Sci 16(3): 1-8. doi: 10.9734/jamps/2018/40775

Pratiwi E, Rivai H. 2015. Production and characterization of water extract of meniran herb (Phyllanthus niruri Linn) (in Indonesian). Jurnal Penelitian Farmasi Indonesia, 3(2): 54-9.

Procter HR, Brumwell H, Stiasny E. 1966. Leather chemists pocket book: a short compendium of analytical methods. Spon and Chamberlain.

Rivai H, Sari DP, Rizal Z. 2012. Isolation and characterization of antioxidant flavonoids from meniran herb (Phyllanthus niruri L.) (in Indonesian) Jurnal Farmasi Higea, 4(2), 87-95. doi: 10.52689/higea.v4i2.66

Row LR, Srinivasulu C, Smith M, Rao GSRS. 1964. New lignans from Phyllanthus niruri Linn. Tetrahedron Lett 24: 1557-67. doi: 10.1016/0040-4039(64)83053-7

Singh MK, Ahmad MS. 2020. Phytochemical profile of Phyllanthus niruri 1 and evaluation of its potent bioactive compounds. Biosci Biotechnol Res Commun 13(3): 1545-51. doi: 10.21786/bbrc/13.3/82

Somanabandhu A, Nitayangkura S, Mahidol C, Ruchirawat S, Likhitwitayawuid K, Shieh HL, Chai H, Pezzuto JM, Cordell GA. 1993 1H- and 13C-NMR assignments of phyllanthin and hypophyllanthin: lignans that enhance cytotoxic responses with cultures multidrugresistant cells. $J$ Nat Prod 56(2): 233-9. doi: 10.1021/np50092a008

Tambunan RM, Swandiny GF, Zaidan S. 2019. Antioxidant activity assay of $70 \%$ ethanol extract of standardized meniran herb (Phyllanthus niruri L.) (in Indonesian). Jurnail Ilmu Kefarmasian 12(2): 60-64. doi: $10.37277 /$ sfj.v12i2.444

Tripathi AK, Verma RK, Gupta AK, Gupta MM, Khanuja SPS. 2006 Quantitative determination of phyllanthin and hypophyllanthin in Phyllanthus species by high-performance thin layer chromatography. Phytochem Anal 17(6): 394-7. doi: 10.1002/pca.936

Wang HM, Chen CY, Chen CY, Ho ML, Chou YT, Chang HC, Lee CH, Wang CZ, Chu IM. 2010. (-)-N-Formylanonaine from Michelia alba as a human tyrosinase inhibitor and antioxidant. Bioorg Med Chem 18(14): 5241-7. doi: $10.1016 / \mathrm{j}$. bmc.2010.05.045

World Health Organization. 2011. Quality control methods for herbal materials. Geneva: WHO, pp. 173

Zolghadri S, Bahrami A, Hassan Khan MT, Munoz-Munoz J, Garcia-Molina F, Garcia-Canovas F, Saboury AA. 2019. A comprehensive review on tyrosinase inhibitors. $J$ Enzym Inhib Med Ch 34(1): 279-309. doi: $10.1080 / 14756366.2018 .1545767$ 